\title{
QUANTITATIVE CHANGES IN THE BIOCHEMICAL COMPOSITION OF LIGNOCELLULOSIC RESIDUES DURING THE VEGETATIVE GROWTH OF LENTINULA EDODES
}

\author{
Rigoberto Gaitán-Hernández ${ }^{1, *}$, Martín Esqueda², Aldo Gutiérrez ${ }^{2}$, Miguel Beltrán-García ${ }^{3}$ \\ ${ }^{1}$ Instituto de Ecología A.C., P.O. Box 63, Xalapa, 91000, Veracruz, México; ${ }^{2}$ Centro de Investigación en Alimentación y \\ Desarrollo A.C., P.O. Box 1735, Hermosillo, 83000, Sonora, México; ${ }^{3}$ Universidad Autónoma de Guadalajara. P.O. Box 1-440, \\ Guadalajara, 44100, Jalisco, México.
}

Submitted: June 03, 2010; Approved: August 23, 2010.

\begin{abstract}
The chemical changes in barley-straw (BS), wheat-straw (WS) and vineyard-pruning (VP) substrates were determined during colonization of Lentinula edodes mycelia (during primordium development) in solid state fermentation. Primordia appeared 39-50 days after inoculation. VP appeared to promote early sporophore initiation. The concentration of hemicellulose in BS and VP decreased gradually from $25.5 \%$ to $15.6 \%$ and from $15.8 \%$ to $12.3 \%$, respectively. However in WS, hemicellulose decreased from $27.2 \%$ to $9.5 \%$. Lignin broke down continuously in BS and WS, with $31.8 \%$ and $34.4 \%$ degradation, respectively; higher than that of cellulose. During the pinning stage, the C:N ratio decreased in VP and BS, but not in WS. On all substrates the phenols decreased notably throughout the first week of mycelial growth. The time elapsed (days) to pinning was positively correlated with cellulose content $(r=0.89)$, total sugar $(r=0.85)$ and inversely correlated to lignin $(r=-1.00)$ and phenol content $(r=-0.55)$.
\end{abstract}

Key words: agricultural residues, vegetative growth, chemical properties, shiitake mushroom

\section{INTRODUCTION}

Commercial interest in the shiitake mushroom [Lentinula edodes (Berk.) Pegler] has increased in recent years, mainly because of its high value on the international market and an increase in dried mushrooms imports by some countries. The latter has occurred, not only because of its excellent aroma, flavor and nutritional profile, but also because of its medicinal properties $(19,56)$. Among all the edible mushrooms cultivated worldwide, shiitake occupies second place (7). China dominates the world market for this mushroom, because the successful production of this crop on shavings has continually increased its production in recent decades. China produced 1,388,000 tons of shiitake in 1998 and 2,228.000 tons in 2003 (6, 26). L. edodes cultivation has been extended to other countries and has increased, mostly due to better production systems and greater demand by consumers (44). In Latin America ca. 870 tons of shiitake were produced in 2002, with Brazil the main producer at $92 \%$ and Mexico producing $3.45 \%$ (18.2 tons) of the total $(20,27)$. 
The most common alternative substrates for shiitake production in Mexico and other Latin American countries are: Carpinus, Bursera, Alnus and Heliocarpus shavings (29, 32, 33), coffee pulp, wheat straw, sugar cane bagasse and the sawdust of different types of wood $(14,28,38,45)$. However, availability of some of these substrates is limited. Other lignocellulosic agricultural wastes such as straws from different cereals and vineyard prunings have great potential due to their chemical characteristics and abundance. In Mexico ca. 250,000 tons of vineyard pruning (wood cuttings resulting from pruning grapevines) are produced every year. In addition, ca. 0.7 and 2.7 million tons of barley straw waste and wheat straw waste are produced annually (FAO 2004. http://www.fao.org/index_en.htm.). For the agricultural sector of the economies in temperate and subtropical countries it is important to recognize the value of the agricultural residues left over from the cultivation of various crops (37).

These days, much of the research done on mushrooms that have nutritional or pharmacological value focuses on the development of cultivation strategies that make it easy to obtain target compounds. Therefore, adopting modern practices of fermentation or cultivation can lead to larger harvests and other advantages. For example, an increase in early fruiting will reduce production time.

Shiitake cultivation involves two phases in order to support different physiological stages of the fungus: 1 . vegetative growth and 2 . fruit body formation. Culture conditions such as moisture content, genotype and substrate composition influence mycelial growth. The length of the vegetative stage and the various chemical changes in the substrate can have a significant impact on fruiting capacity. It has been reported that the length of the spawn run can greatly affect mushroom yield $(35,43)$.

To develop an efficient cultivation method for growing mushrooms on cereal straw and vineyard prunings, and to provide information on how to best use the substrate for shiitake production on a commercial scale, it is important to know how the mycelium uses the nutritional elements provided by these non-conventional substrates. Therefore, the objective of this study was to evaluate chemical modifications in three non-conventional substrates subjected to solid state fermentation by four strains of Lentinula edodes under green house conditions. Changes in the concentrations of lignin, cellulose and hemicellulose, and their correlations during mycelial growth prior to fruit body production were determined. This is expected to improve our understanding of the differential utilization of diverse constituents of agricultural lignocellulosic residues during the vegetative growth phase.

\section{MATERIALS AND METHODS}

Four strains of L. edodes (IE-105, IE-123, IE-245 and IE247) were used. All are deposited in the Fungus Culture Collection at the Institute of Ecology (Xalapa, Mexico). The strains were kept in pure cultures on malt extract agar (MEA) (BIOXON, USA) at $25^{\circ} \mathrm{C}$.

Cultures were grown on barley straw BS (Hordeum vulgare L.), wheat straw WS (Triticum aestivum L.) and vineyard prunings VP (Vitis vinifera L.). Substrates and grain spawn were prepared as previously described by GaitánHernández and Mata (14) and Gaitán-Hernández et al., (15). The vegetative developmental stage occurred at $25^{\circ} \mathrm{C}$; this is an optimal temperature for shiitake (7) and a key factor in regulating most of the fungus' metabolism. For primordium formation, the temperature was lowered to $16-20^{\circ} \mathrm{C}$ (10). Air recirculation was used for cooling, to maintain air distribution, to increase oxygen levels and reduce $\mathrm{CO}_{2}$. The concentration of $\mathrm{CO}_{2}$ was kept below $1000 \mathrm{ppm}$, as recommended for the proper primordium development $(39,52)$. In $L$. edodes the moisture content of the substrate and the relative humidity of the air during vegetative growth and primordium formation have a direct effect on mycelial growth given that they influence both nutrient availability and fungal degradation.

Colonized substrates were subjected to proximate 
analysis. Dry samples ( $2 \mathrm{~g} / \mathrm{sample}$ and each constituent) were powdered and analyzed immediately for several constituents: total mineral (AOAC 4.1.10, method 942.05) (2), crude fat (AOAC 4.5.01, method 920.39) (2), crude protein ( $\mathrm{N} \times 6.25$ ) (AOAC 4.2.08, method 934.01) (2); and Neutral Detergent Fiber (NDF), which is comprised of hemicellulose, cellulose, and lignin (cellulose content was calculated by the differences between ADF-lignin; hemicellulose by the difference between NDF-ADF) as determined by Goering \& Van-Soest's technique (16). Total phenol content was estimated according to the procedure outlined by Box (4) and total sugar content was determined using the Phenol- $\mathrm{H}_{2} \mathrm{SO}_{4}$ colorimetric method (12). The C:N ratio was assessed according to Sánchez \& Royse (13), where $\mathrm{C}: \mathrm{N}=\% \mathrm{C} / \% \mathrm{~N}$, and $\mathrm{C}(\%)=0.58 \mathrm{x}$ organic matter (\%). Control samples were taken at day 0 (noninoculated substrates) and at two stages of L. edodes mycelial development: after 8 days of incubation and prior to primordium formation (day 39 to 50 ).

Data was analyzed using a two-way analysis of variance. The mean values were separated by Duncan's multiple range test $(\alpha<0.05)$. Correlation analyses were carried out to determine the relationship between the chemical constituents of the substrates and the days to primordium formation. All statistical analyses were performed using SAS 8.02 statistical package for Windows (48).

\section{RESULTS AND DISCUSSION}

Primordium development occurred on all substrates. The shortest mean time to the appearance of the primordia was recorded on VP, while for both types of straw primordium formation took considerably longer. Mean time from inoculation to pinning on BS, WS and VP was 48, 50 and $39 \mathrm{~d}$, respectively. The IE-245 strain took less time to start fruiting, with an average of $31 \mathrm{~d}$, while average time for the other three strains fluctuated between 43 (IE-123) and $57 \mathrm{~d}$ (IE-247) for the three substrates. VP was the best substrate for IE-245 based on early primordium formation (28 d) (15). After the incubation period, only the VP samples showed dark-colored patches that eventually spread to cover the entire surface, indicating a ripe mycelium ready for fructification $(11,39)$.

There were significant differences in the fat content of the substrate for the three sampling periods $(\alpha<0.05)$, with a tendency for it to decrease in all substrates during primordium formation in all shiitake strains (Figure 1). This decrease could result from differing energy requirements by the mushroom depending on its stage of growth. Chantaraj (8) mentioned that during substrate degradation by $L$. edodes, the percentage of fat tends to decrease as it is used as an energy source that stimulates the growth of the mushroom $(50,51)$.

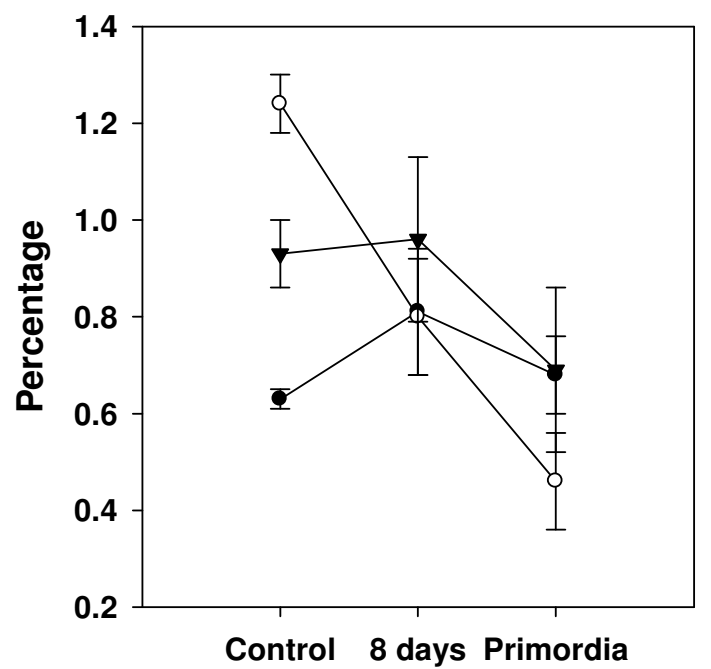

Figure 1. Variation in fat content (average) of substrates during mycelial growth of four strains of L. edodes. Barley straw (BW) ( $\boldsymbol{\nabla})$, wheat straw (WS) (-O-), and vineyard pruning (VP) (--).

Differences in percentage of protein (based on dry matter) in the substrates evaluated at different mycelial growth stages of L. edodes are shown in Figure 2. Significant differences were found between the stages analyzed $(\alpha<0.05)$. Total protein content in the control was greater in WS and lower in 
BS. After 8 days of incubation and prior to primordium formation, concentration of protein in VP and BS substrates increased relative to that of the control, from $4.98 \%$ to $5.21 \%$ and from $3.89 \%$ to $4.96 \%$, respectively. This result agrees with those of other authors who also evaluated substrates inoculated with shiitake (24). This increase in protein content is attributed to the fungus residues left in the substrate analyzed. It might also result from some microorganism associated with the fungus that has the ability to fix nitrogen from the atmosphere, resulting in an increase in the substrate's nitrogen content (42).

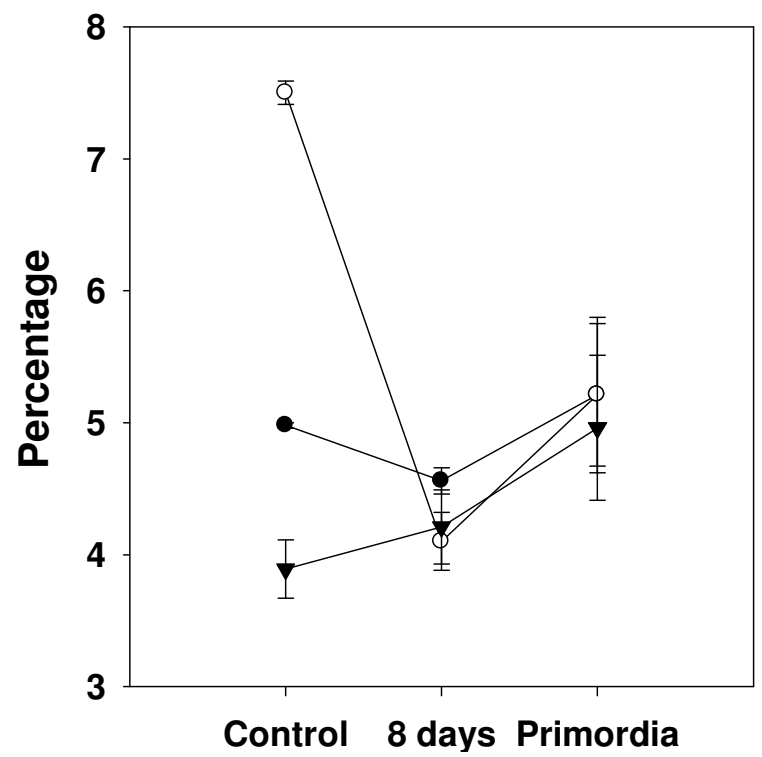

Figure 2. Variation in protein content (average) of substrates during mycelial growth of four strains of L. edodes. BS ( $\longrightarrow \boldsymbol{\nabla})$, WS (-○一), and VP (--).

Fiber (NDF) is mainly composed of cellulose, hemicellulose and lignin. Figure 3 shows the percentage of NDF (based on dry matter) for the substrates inoculated with $L$. edodes: WS (69.1\%), BS (87.1\%) and VP (71.9\%). NDF was different among substrates and among stages $(\alpha<0.05)$. NDF increased in WS and BS substrates after 8 days of mycelial growth but this increase was not significant in BS after 8 days of growth (Figure 3). Conversely, NDF decreased relative to the control during the primordium formation stage. A slight increase in NDF in VP was observed and was significantly different from the control $(\alpha>0.05)$. The decrease in NDF content in WS was ca. $0.5 \%$, while in BS it was ca. $17 \%$. The initially high NDF content $(87.1 \%)$ in BS coincides with the high mushroom production on this substrate as previously reported by Gaitán-Hernández et al. (15). They stated that mean biological efficiency (BE: ratio of fresh mushroom/substrate dry weight, expressed in percentages) on VP varied between $44.61 \%$ (IE-247) and 93.25\% (IE-245), with an average $\mathrm{BE}$ of $59.32 \%$ and no statistical difference among three of the four strains evaluated. The highest BE was also recorded for strain IE-247 $(88.60 \%)$ on BS, with no difference from the rest of the strains $(\alpha>0.05)$. The best BE was obtained with IE-245 (78.48\%) on WS and no significant difference was observed for the other three strains. The highest mean BE per substrate was observed on BS (77.6\%), and this was significantly different from that obtained on VP and WS.

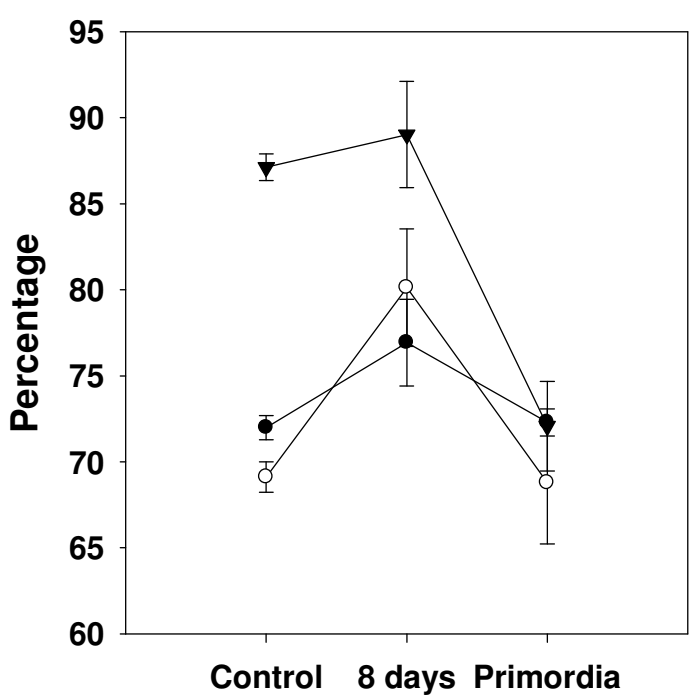

Figure 3. Variation in Neutral Detergent Fiber (average) of substrates during mycelial growth of four strains of L.edodes.

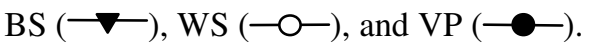


Variation in the phenol content of substrates is an important aspect in the adaptation of shiitake strains since the capacity of a substrate to resist degradation has been partially attributed to its array of phenolic compounds (13). In the present study, significant differences were observed in the total phenol content among substrates before and after being inoculated with shiitake (Figure 4). The drastic decrease between the control substrate and the first stage ( 8 days) may result from the sensitivity of the free phenols to the high temperatures used to sterilize the substrate, or to the activity of certain enzymes synthesized by shiitake mycelia, such as laccase and $\mathrm{Mn}$ peroxidase that catalyze the oxidation of phenols to phenoxyl radicals $(5,18,34)$. Also, this initial decrease in the phenolic content of the substrate shows the capacity of shiitake to neutralize the toxic effects of some of the intrinsic monomers. A notable decrease in substrate phenols has also been reported for the first stages of growth in Pleurotus sp., concurrent with high Mn peroxidase activity. The activity of Mn peroxidase and laccase enzymes is linked to a response of the mushroom to oxidize chemical compounds and decrease their toxic effects $(54,55)$. Zheng and Shetty $(58)$ have also mentioned that L. edodes has high levels of extracellular enzymes, such as $\beta$-glucosidases, that are capable of hydrolyzing phenolic compounds. In the advanced stages of growth, this explains the progressive increase in phenols and the enhancement of mycelial growth in Lentinula spp. (3). Therefore, Leonowicz et al. (25) have mentioned that the laccase oxidizes the lignin-derived radicals to quinones and that these quinones can serve as a source of oxygen for the glucose oxidase enzyme (GOD). GOD cooperates with LiP and MnP providing $\mathrm{H}_{2} \mathrm{O}_{2}$ and along with the laccase, reduces the quinones to phenols. That is, an excess of quinones and their possible polymerization are offset by the activity of GOD, which reduces them to their respective phenols. It is possible that it is these phenols that are detected after the fungus has been growing for a certain length of time.

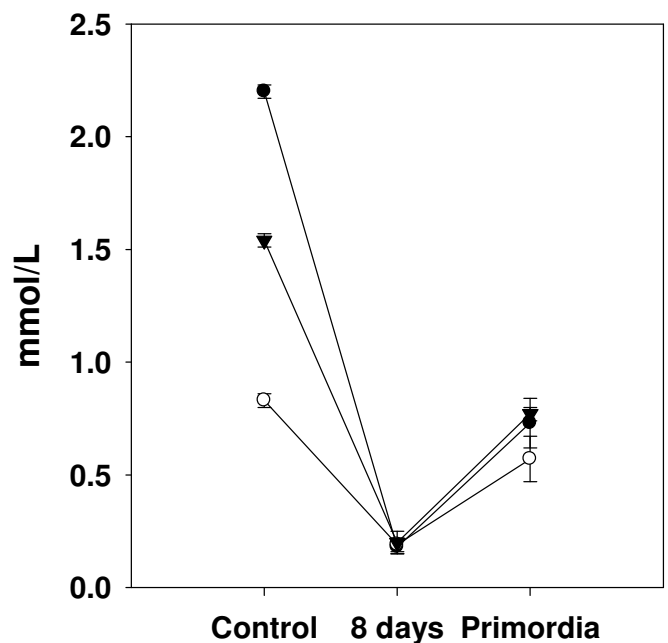

Figure 4. Variation in total phenol content (average) of substrates during mycelial growth of four strains of $L$. edodes.

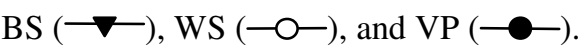

The initial concentration of hemicellulose, cellulose and lignin (Table 1) varied among substrates $(\alpha<0.05)$, with the highest levels of cellulose and lignin in VP and BS. The highest concentration of lignin $(14.6 \%)$ in VP promoted first the utilization of cellulosic carbon as an energy source. Later, during the primordium formation stage, shiitake mycelia used lignin. In BS and VP, the hemicellulose concentration decreased gradually from $25.5 \%$ (control) to $15.6 \%$ (primordia) and from $15.8 \%$ to $12.3 \%$, respectively. However, the decrease in WS was drastic; from $27.2 \%$ to $9.5 \%$ and, owing to the method of measurement used in this study, cellulose increased. This agrees with the findings of Leatham (21) who observed that hemicellulase activity in glucoronic-xylan polymers was constant during the initial periods of mycelial growth in shiitake. Leatham (21) observed that hemicellulose activity in glucuronic-xylan polymers was constant during the initial and intermediate periods of shiitake growth, while proteinase activity was detected during the intermediate growth stage and polygalacturonase activity was high throughout development. He also found that endoglucanase and $\beta$-glucosidase activity 
increased slightly at the time of fruiting. Mata et al. (30) have mentioned that endoglucanase production is associated with other primordium and fruiting formation stages where there has been a significant increase in enzymatic activity. As we found in this study, Leatham and Leonard (22) mentioned that, during mycelial growth, L. edodes uses the most accessible sources of carbon, such as free sugars, starch, pectins and hemicelluloses. Our results also agree with those of Van et al. (53) who observed that during the first stages of shiitake growth, cellulose and other simple compounds remain the most abundant components of the substrate, while lignin is almost completely degraded. This is attributed to low cellulase and high ligninase activity. In addition, the degradation pattern observed for hemicellulose and lignin was very similar within the same substrate, owing to the close association between both compounds, a characteristic that has been mentioned by Zelenak (57). Harris-Valle et al. (17) observed that polar vineyard pruning extracts enhanced both biomass production and the activity of the main ligninolytic enzymes (lignin peroxidase, manganese peroxidase, aryl alcohol oxidase, and laccase) in Lentinula edodes liquid cultures.

Table 1. Composition of Barley Straw (BS), Vineyard Pruning (VP), and Wheat Straw (WS) during solid state fermentation upon pinning of Lentinula edodes.

\begin{tabular}{|c|c|c|c|c|c|c|c|c|}
\hline Stage & Strain & Substrate & $\operatorname{Ash}^{1}$ & Total sugar (mg/g) & $\mathrm{C}: \mathrm{N}$ ratio & Cellulose & Hemicellulose & Lignin \\
\hline \multirow{3}{*}{ Control } & - & $\mathrm{BS}$ & $6.45 \pm 0.10^{\mathrm{h}, \mathrm{i}}$ & $42.22 \pm 1.55^{\mathrm{t}}$ & $61.09 \pm 0.06^{\mathrm{b}}$ & $48.39 \pm 0.16^{\mathrm{b}-\mathrm{e}}$ & $25.51 \pm 0.73^{\mathrm{a}, \mathrm{b}}$ & $13.22 \pm 1.35^{\mathrm{d}-\mathrm{g}}$ \\
\hline & - & VP & $3.18 \pm 0.02^{\mathrm{k}}$ & $209.41 \pm 0.91^{\mathrm{j}-\mathrm{m}}$ & $49.40 \pm 0.01^{\mathrm{j}}$ & $41.47 \pm 2.05^{\mathrm{f}-\mathrm{i}}$ & $15.82 \pm 0.16^{\mathrm{c}, \mathrm{d}}$ & $14.69 \pm 2.92^{\mathrm{b}-\mathrm{e}}$ \\
\hline & - & WS & $7.79 \pm 0.07^{\mathrm{d}-\mathrm{f}}$ & $196.68 \pm 1.96^{1, \mathrm{~m}}$ & $31.23 \pm 0.02^{\mathrm{s}}$ & $29.34 \pm 1.39^{j}$ & $27,28 \pm 2.02^{\mathrm{a}}$ & $12.50 \pm 2.53^{\mathrm{d}-\mathrm{h}}$ \\
\hline \multirow{12}{*}{8 days } & & BS & $5.53 \pm 0.21^{\mathrm{j}}$ & $167.28 \pm 3.71^{\mathrm{p}-\mathrm{r}}$ & $54.88 \pm 0.12^{\mathrm{f}}$ & $49.43 \pm 0.65^{\mathrm{b}-\mathrm{e}}$ & $30.48 \pm 1.11^{\mathrm{a}}$ & $13.53 \pm 2.03^{\mathrm{c}-\mathrm{f}}$ \\
\hline & 105 & VP & $6.77 \pm 0.28^{\mathrm{g}, \mathrm{h}}$ & $162.61 \pm 4.32^{\mathrm{r}}$ & $51.69 \pm 0.16^{\mathrm{h}}$ & $39.02 \pm 1.18^{\mathrm{h}, \mathrm{i}}$ & $15.46 \pm 0.05^{\mathrm{c}, \mathrm{d}}$ & $19.49 \pm 0.21^{\mathrm{a}-\mathrm{c}}$ \\
\hline & & WS & $7.72 \pm 0.12^{\mathrm{e}-\mathrm{g}}$ & $220.22 \pm 2.49^{\mathrm{i}, \mathrm{j}}$ & $60.42 \pm 0.08^{c}$ & $55.47 \pm 1.77^{\mathrm{a}}$ & $13.25 \pm 0.00^{\mathrm{c}-\mathrm{e}}$ & $9.72 \pm 0.72^{\mathrm{d}-\mathrm{h}}$ \\
\hline & & BS & $5.49 \pm 0.15^{\mathrm{j}}$ & $179.24 \pm 4.46^{\mathrm{o}-\mathrm{q}}$ & $62.34 \pm 0.10^{\mathrm{a}}$ & $48.01 \pm 2.44^{\mathrm{b}-\mathrm{e}}$ & $27.94 \pm 1.63^{\mathrm{a}}$ & $12.55 \pm 1.66^{\mathrm{d}-\mathrm{h}}$ \\
\hline & 123 & VP & $7.98 \pm 0.32^{\mathrm{d}-\mathrm{f}}$ & $272.49 \pm 4.93^{\mathrm{e}}$ & $51.77 \pm 0.18^{\mathrm{h}}$ & $38.95 \pm 1.75^{\mathrm{h}, \mathrm{i}}$ & $17.31 \pm 0.44^{\mathrm{c}, \mathrm{d}}$ & $21.28 \pm 1.37^{\mathrm{a}}$ \\
\hline & & WS & $8.41 \pm 0.20^{\mathrm{d}, \mathrm{e}}$ & $211.88 \pm 6.09^{\mathrm{j}, \mathrm{k}}$ & $56.59 \pm 0.12^{\mathrm{e}}$ & $50.89 \pm 1.14^{\mathrm{a}-\mathrm{d}}$ & $15.84 \pm 0.72^{\mathrm{c}, \mathrm{d}}$ & $9.17 \pm 0.96^{\mathrm{d}-\mathrm{h}}$ \\
\hline & & BS & $5.78 \pm 0.19^{\mathrm{i}, \mathrm{j}}$ & $181.01 \pm 2.67^{\mathrm{o}, \mathrm{p}}$ & $53.53 \pm 0.11^{\mathrm{g}}$ & $50.99 \pm 0.83^{\mathrm{a}-\mathrm{d}}$ & $26.13 \pm 2.68^{\mathrm{a}}$ & $11.13 \pm 1.65^{\mathrm{d}-\mathrm{h}}$ \\
\hline & 245 & VP & $8.54 \pm 0.15^{\mathrm{d}}$ & $181.81 \pm 8.55^{\mathrm{n}, \mathrm{o}}$ & $49.98 \pm 0.08^{\mathrm{i}}$ & $39.90 \pm 0.36^{\mathrm{g}-\mathrm{i}}$ & $16.31 \pm 1.26^{\mathrm{c}, \mathrm{d}}$ & $19.93 \pm 0.48^{\mathrm{a}, \mathrm{b}}$ \\
\hline & & WS & $8.33 \pm 0.19^{\mathrm{d}, \mathrm{e}}$ & $234.70 \pm 4.54^{\mathrm{g}, \mathrm{h}}$ & $56.97 \pm 0.12^{\mathrm{d}, \mathrm{e}}$ & $53.35 \pm 0.40^{\mathrm{a}, \mathrm{b}}$ & $16.65 \pm 2.65^{\mathrm{c}, \mathrm{d}}$ & $13.54 \pm 0.85^{\mathrm{c}-\mathrm{f}}$ \\
\hline & & BS & $6.52 \pm 0.25^{\mathrm{h}, \mathrm{i}}$ & $202.13 \pm 6.31^{\mathrm{k}-\mathrm{m}}$ & $57.42 \pm 0.15^{\mathrm{d}}$ & $47.12 \pm 1.16^{\mathrm{c}-\mathrm{f}}$ & $28.09 \pm 1.65^{\mathrm{a}}$ & $10.67 \pm 1.36^{\mathrm{d}-\mathrm{h}}$ \\
\hline & 247 & VP & $8.43 \pm 1.07^{\mathrm{d}, \mathrm{e}}$ & $195.36 \pm 4.40^{\mathrm{m}, \mathrm{n}}$ & $51.66 \pm 0.60^{\mathrm{h}}$ & $38.41 \pm 1.32^{\mathrm{i}}$ & $18.73 \pm 3.45^{\mathrm{c}}$ & $22.91 \pm 2.88^{\mathrm{a}}$ \\
\hline & & WS & $8.33 \pm 0.29^{\mathrm{d}, \mathrm{e}}$ & $210.76 \pm 6.71^{\mathrm{j}-1}$ & $53.66 \pm 0.17^{\mathrm{g}}$ & $51.71 \pm 0.04^{\mathrm{a}-\mathrm{c}}$ & $19.35 \pm 1.36^{\mathrm{b}, \mathrm{c}}$ & $11.06 \pm 1.13^{\mathrm{d}-\mathrm{h}}$ \\
\hline \multirow{12}{*}{$\begin{array}{l}\text { Primordium } \\
\text { formation }\end{array}$} & & BS & $7.15 \pm 0.22^{\mathrm{f}-\mathrm{h}}$ & $248.10 \pm 2.35^{\mathrm{f}, \mathrm{g}}$ & $49.27 \pm 0.12^{\mathrm{j}}$ & $48.63 \pm 1.05^{\mathrm{b}-\mathrm{e}}$ & $17.85 \pm 0.71^{\mathrm{c}}$ & $8.91 \pm 0.31^{\mathrm{e}-\mathrm{h}}$ \\
\hline & 105 & VP & $11.27 \pm 0.21^{\mathrm{a}}$ & $101.63 \pm 9.12^{\mathrm{s}}$ & $48.27 \pm 0.11^{\mathrm{k}}$ & - & - & - \\
\hline & & WS & $11.05 \pm 0.26^{\mathrm{a}}$ & $202.86 \pm 5.09^{\mathrm{k}-\mathrm{m}}$ & $45.96 \pm 0.14^{\mathrm{m}}$ & $50.81 \pm 0.77^{\mathrm{a}-\mathrm{d}}$ & $8.08 \pm 0.29^{\mathrm{e}, \mathrm{f}}$ & $6.62 \pm 0.98^{\mathrm{h}}$ \\
\hline & & BS & $8.13 \pm 0.30^{\mathrm{d}, \mathrm{e}}$ & $287.06 \pm 4.73^{\mathrm{d}}$ & $54.74 \pm 0.18^{\mathrm{f}}$ & $46.50 \pm 0.24^{\mathrm{c}-\mathrm{f}}$ & $13.50 \pm 0.90^{\mathrm{c}-\mathrm{e}}$ & $9.58 \pm 0.03^{\mathrm{d}-\mathrm{h}}$ \\
\hline & 123 & VP & $8.40 \pm 0.24^{\mathrm{d}, \mathrm{e}}$ & $324.49 \pm 1.49^{b}$ & $40.51 \pm 0.11^{\mathrm{q}}$ & $45.62 \pm 1.54^{\mathrm{d}-\mathrm{g}}$ & $1154 \pm 0.10^{\mathrm{d}-\mathrm{f}}$ & $14.86 \pm 1.06^{\mathrm{b}-\mathrm{e}}$ \\
\hline & & WS & $9.74 \pm 0.21^{\mathrm{c}}$ & $258.44 \pm 3.29^{\mathrm{e}, \mathrm{f}}$ & $49.58 \pm 0.12^{\mathrm{i}, \mathrm{j}}$ & $51.96 \pm 3.71^{\mathrm{a}-\mathrm{c}}$ & $6.37 \pm 2.48^{\mathrm{f}}$ & $10.90 \pm 2.91^{\mathrm{d}-\mathrm{h}}$ \\
\hline & & BS & $6.86 \pm 0.10^{\mathrm{h}}$ & $347.68 \pm 0.82^{\mathrm{a}}$ & $45.21 \pm 0.05^{\mathrm{n}}$ & $49.77 \pm 0.73^{\mathrm{a}-\mathrm{e}}$ & $15.80 \pm 0.06^{\mathrm{c}, \mathrm{d}}$ & $7.54 \pm 0.35^{\mathrm{f}-\mathrm{h}}$ \\
\hline & 245 & VP & $10.47 \pm 0.53^{\mathrm{a}-\mathrm{c}}$ & $166.34 \pm 5.49^{\mathrm{q}, \mathrm{r}}$ & $47.41 \pm 0.28^{1}$ & $44.30 \pm 2.18^{\mathrm{e}-\mathrm{i}}$ & $13.14 \pm 0.99^{\mathrm{c}-\mathrm{e}}$ & $15.10 \pm 1.98^{\mathrm{b}-\mathrm{d}}$ \\
\hline & & WS & $9.78 \pm 0.24^{\mathrm{c}}$ & $306.29 \pm 2.94^{c}$ & $42.84 \pm 0.11^{\circ}$ & $51.45 \pm 0.24^{\mathrm{a}-\mathrm{d}}$ & $7.79 \pm 0.01^{\mathrm{e}, \mathrm{f}}$ & $7.25 \pm 0.59^{\mathrm{g}, \mathrm{h}}$ \\
\hline & & BS & $8.21 \pm 0.19^{\mathrm{d}, \mathrm{e}}$ & $250.85 \pm 0.55^{\mathrm{f}}$ & $41.85 \pm 0.09^{p}$ & $44.64 \pm 0.79^{\mathrm{e}-\mathrm{h}}$ & $15.52 \pm 2.75^{\mathrm{c}, \mathrm{d}}$ & $10.03 \pm 0.29^{\mathrm{d}-\mathrm{h}}$ \\
\hline & 247 & VP & $10.21 \pm 0.25^{\mathrm{b}, \mathrm{c}}$ & $179.07 \pm 4.28^{\mathrm{o}-\mathrm{q}}$ & $40.55 \pm 0.11^{\mathrm{q}}$ & - & - & - \\
\hline & & WS & $10.87 \pm 0.14^{\mathrm{a}, \mathrm{b}}$ & $228.63 \pm 1.83^{\mathrm{h}, \mathrm{i}}$ & $38.11 \pm 0.06^{\mathrm{r}}$ & $50.01 \pm 1.73^{\mathrm{a}-\mathrm{e}}$ & $15.84 \pm 0.80^{\mathrm{c}, \mathrm{d}}$ & $8.01 \pm 0.18^{\mathrm{f}-\mathrm{h}}$ \\
\hline
\end{tabular}

All values are means \pm the standard deviation (SD) of samples in triplicate. Means in a column with different superscripts are significantly different $(\alpha<$ 0.05 , Duncan). ${ }^{1}$ Ash, C:N, Cellulose, Hemicellulose and Lignin values are percentages (d.w. basis). 
In BS and WS substrates, lignin was continuously broken down by shiitake during the primordium formation stage, with $31.8 \%$ and $34.4 \%$ degradation respectively; both values greater than that of cellulose (Table 1). These results coincide with those of Morais et al. (31), who mentioned that when shiitake grows on lignocellulose substrates, cellulose degradation is lower than that of lignin. Throughout mycelial growth, the percentage biodegradation in both types of cereal straw was generally greater than that of the vineyard prunings. However primordium production on the latter took less time, indicating that shiitake has a greater assimilation capacity on this substrate. According to our results, the lignin degradation capacity of shiitake was different on cereal straw as compared to vineyard prunings, mainly because of differences in the composition of the primary polymers in the lignin complex. This probably affected the affinity of the mushroom's enzymes for the substrate. The activity of these enzymes depends on the composition of the substrate and environmental conditions (31).

During the vegetative growth of shiitake on the three substrates, the ash concentration increased steadily relative to the control. Significant differences were observed between stages, with a greater quantity of minerals during the advanced stages of culture. Ash content increased more than $300 \%$ in VP and more than $100 \%$ in WS and BS (Table 1). Thus, a relative increase in the ash content was observed during the course of degradation of the substrate and utilization of its components (41). Chantaraj (8) and Sánchez et al. (47) proposed that an increase in mineral content is one of the changes that substrates undergo during enzymatic breakdown and the resulting organic matter is utilized while the fungi are in the vegetative development stage. The low initial mineral content in vineyard prunings is common to the types of wood commonly used for shiitake cultivation (22). However, it is the type of minerals and not the quantity in the substrate that is a key factor for good mushroom development. In Lentinula edodes, Leatham and Stahmann (23) reported that the growth and development of shiitake are strongly affected by mineral concentration. In our results, even though the vineyard prunings had the lowest initial mineral concentration, shiitake grown on this substrate had the shortest time from inoculation to pinning (Table 1).

The carbon to nitrogen ratio $(\mathrm{C}: \mathrm{N})$ in the control was different from that of the colonized substrates, but during shiitake's growth phase the ratio varied depending on the strain and the substrate (Table 1). In the primordium formation stage, $\mathrm{C}: \mathrm{N}$ ratio in VP and $\mathrm{BS}$ decreased, but this did not happen on WS. BS and VP had the highest initial C:N content and were the substrates on which primordium production occurred earlier. This has also been reported by Philippoussis et al. (36) who observed that mycelial growth and fructification on wheat straw was similar to that of oak shavings; favored by the high nitrogen content of the straw. Stamets (52) anticipated that C:N ratio and equilibrium values for $\mathrm{C}: \mathrm{N}$ favor optimal fungal growth, and lack of equilibrium decreases or halts development. Nitrogen is essential for mushrooms hence its concentration in the substrate has a direct effect on their development. Nitrogen concentration changes modify substrate $\mathrm{pH}$ and affect the ability of the mushroom to establish $(22,39)$. The decrease in C:N observed in BS and WS agrees with the findings of Sánchez and Royse (46) who stated that after cultivating and harvesting mushrooms, the $\mathrm{C}: \mathrm{N}$ ratio in the substrate decreases.

Sugar content for the different stages, strains and substrates studied are shown in Table 1. Significant differences among stages were found. The two types of cereal straw had a tendency to increase total sugar compared to the control, while the sugar content of VP substrate declined during the spawn run phase. In WS, total sugar increased $26.6 \%$ in the primordium formation stage while an increase of more than $500 \%$ was observed in BS. Chantaraj (8) noted that after the mushrooms have grown, the compounds in the substrate are more soluble with three to five times more free sugar. Similarly, Rajarathnam et al. (40), showed that Pleurotus flabellatus cultivated on rice straw also promoted a continuous 
increase in sugars during initial mycelial growth followed by a decrease during the fruiting stage. This is possibly associated with the energetic requirements for initiating fructification. Mushrooms need easily assimilated sources of carbon and available sugars. These accelerate mushroom growth and the degradation of the medium, and also reduce fructification time since the mycelium will convert these carbohydrates into reserves for fruiting (39).

Correlation studies between the constituents of the substrates and the number of days to primordium formation (Table 2) revealed a significant $(\alpha<0.05)$ positive relationship with cellulose content $(r=0.89)$ and total sugar $(r=0.85)$, indicating that cellulose and sugar content in each substrate were directly proportional to the primordium formation. The carbon and sugar from the substrate stimulated L. edodes growth. These substrate constituents are indispensable for the mushroom's enzymatic degradation activity and as compounds that are relatively easy to break down, provide energy for lignin oxidation. Moreover, primordium formation was negatively related to the lignin $(r=-1.00)$ and phenol content ( $r=-0.55)$ of the substrates. The positive relationship obtained in the present study reveals that these components are an important factor in the time elapsed to the emergence of primordia.

Table 2. Correlation between days to primordium formation and substrate constituents.

\begin{tabular}{lc}
\hline $\begin{array}{l}\text { Substrate } \\
\text { constituents }\end{array}$ & $\begin{array}{c}\text { Days to primordium } \\
\text { formation }\end{array}$ \\
\hline Cellulose & $0.89^{*}$ \\
Hemicellulose & -0.12 \\
Lignin & $-1.00^{*}$ \\
Protein & -0.36 \\
C:N & 0.34 \\
Sugar & $0.85^{*}$ \\
Phenols & $-0.55^{*}$ \\
\hline * Significant at 5\% &
\end{tabular}

The results obtained in our study indicate that the chemical composition of the remaining substrate after solidstate fermentation by L. edodes depends on factors such as fungal strain, the availability of various fractions and changes that occur during substrate digestion and mycelial growth. Not only the chemical composition of the substrate influences the adaptation of shiitake to substrate, but other factors such as substrate compaction and moisture level were also determinant.

This study demonstrates that there is a significant correlation between substrate composition and the vegetative growth of L. edodes. The combined activities of cellulases, hemicellulases and ligninolytic enzymes may explain the accelerated vegetative growth and primordium formation in VP (49). The length of the spawn run may greatly affect mushroom yield (43). The data from this experiment demonstrates that the time elapsed to primordium initiation in L. edodes is directly correlated with the cellulose, lignin and total sugar content of the substrate. The correlations observed may offer good parameters for evaluating the period between the inoculation of the substrate and fructification. On the other hand, the bioconversion of non-conventional substrates such as cereal straw and vineyard prunings by shiitake offers a viable alternative use for these abundant agricultural wastes with a double benefit: the cultivation of valuable mushrooms and a reduction in environmental impact. Moreover, the concept of preferential delignification of lignocellulosic materials such as cereal straw and other residues by white-rot fungi has been applied to increase the nutritional value of forage $(1,9)$. This increase in digestibility provides organic carbon that can be fermented to organic acids in an anaerobic environment, such as the rumen.

\section{ACKNOWLEDGMENTS}

The authors wish to express their gratitude to Drs. Jean Michel Savoie (France) and Ruth de León (Guatemala) for donating the strains used in this study. Thanks are also given to Dr. Alma Edith Rodriguez Estrada for her help in the English 
corrections for this paper. B Delfosse revised the final version of the text. This research was funded by the National Council of Science and Technology (CONACyT) of Mexico.

\section{REFERENCES}

1. Agosin, E.; Odier, E. (1985). Solid-state fermentation, lignin degradation and resulting digestibility of wheat straw fermented by selected white-rot fungi. Appl. Microbiol. Biotechnol. 21, 397-403.

2. AOAC. (2000). Official Methods of Analysis of the Association of Official Analytical Chemist. $17^{\text {th }}$ ed. AOAC: Arlington, VA.

3. Beltrán-García, M.; Orozco, A.; Samoya, I.; Ogura, T. (2001). Lignin degradation products from corn stalks enhance notably the radial growth of basidiomycete mushroom mycelia. Rev. Soc. Quím. Méx. 45, 77-81.

4. Box, J.D. (1983). Investigation of the Folin-Ciocalteau phenol reagent for the determination of polyphenolic substances in natural waters. Water Res. 17, 511-525.

5. Buswell, J.A. (1991). Fungal degradation of lignin. In: Arora, D.K.; Rai, B.; Mukerji, K.G.; Knudsen, G.R. (eds). Handbook of applied mycology. Soil and plant. Marcel Dekker, New York, USA, p. 425-480.

6. Chang, S.T. (2005). Witnessing the development of the mushroom industry in China. In: Tan, Q.T.; Zhang, J.; Chen, M.; Cao, H.; Buswell, J.A. (eds). Mushroom biology and mushroom products. Edible Fungi Institute Shanghai Academy of Agricultural Science, Shanghai, p. 3-19.

7. Chang, S.T.; Miles, P.G. (2004). Mushrooms: cultivation, nutritional value, medicinal effect, and environmental impact. CRC Press, Boca Ratón.

8. Chantaraj, N. (2000). Substrates obtained from mushroom cultivation as an alternative feed ingredient. Asian Austral. J. Anim.13, 27-34.

9. Chen, J.; Fales, S.L.; Varga, G.A.; Royse, D.J. (1995). Biodegradation of cell wall components of maize stover colonized by white-rot fungi and resulting impact on in-vitro digestibility. $J$. Sci. Food Agric. 68, 91-98.

10. Donoghue, J.D.; Denison, W.C. (1995) Shiitake cultivation: Gas phase during incubation influences productivity. Mycologia 87, 239-244.

11. Donoghue, J.; Denison, W.C. (1996). Commercial production of shiitake (Lentinula edodes) using whole-log chip of Quercus, Lithocarpus and Acer. In: Royse, D.J. (ed). Mushroom Biology and Mushroom Product. Penn State Univ. Press, Pennsylvania, p. 265-275.

12. Dubois, M.; Gilles, K.A.; Hamilton, J.K.; Rebers, P.A.; Smith, F. (1956). Colorimetric method for determination of sugars and related substances. Anal. Chem.28, 350-356.

13. Fermor, T.R.; Macauley, B.J. (1991). Microbiology factor contributing to selectivity and nutritional quality of mushroom compost. In: Nair, N.G.T. (ed). Proceeding of AMGA/ISMS International Workshop-Seminar of Agaricus Compost, AMGA Limited, Sidney, p. 26-45.

14. Gaitán-Hernández, R.; Mata, G. (2004). Cultivation of edible mushroom Lentinula edodes (shiitake) in pasteurized wheat straw. Alternative use of geothermal energy in Mexico. Eng. Life Sci.4, 363-367.

15. Gaitán-Hernández, R.; Esqueda, M.; Gutiérrez, A.; Sánchez, A.; BeltránGarcía, M. (2006). Bioconversion of agrowastes by Lentinula edodes: the high potential of viticulture residues. Appl. Microbiol. Biot.71, 432-439.

16. Goering, H.K.; Van-Soest, P.J. (1970). Forage fiber analyses (apparatus, reagents, procedures and some applications, Agricultural Research Service, USDA, Agricultural Handbook No. 379. Washington, D.C.

17. Harris-Valle, C.; Esqueda, M.; Sánchez, A.; Beltrán-García, M.; Valenzuela-Soto, E.M. (2007). Polar vineyard pruning extracts increase the activity of the main ligninolytic enzymes in Lentinula edodes cultures. Can. J. Microbiol. 53, 1150-1157.

18. Kirk, T.K.; Farrell, R. (1987). Enzymatic "combustion": The microbial degradation of lignin. Annu. Rev. Microbiol.41, 465-505.

19. Kurtzman, R.H. (2005). Mushrooms: sources for modern western medicine. Micologia Aplicada International 17, 21-33.

20. Lahman, O.; Rinker, D.L. (2004). Mushroom practices and production in Latin America: 1994-2002. In: Rinker, D.L.; Royse, D.J. (eds). Science and cultivation of edible and medicinal fungi. Penn State Univ. Press, Pennsylvania, p. 681-686.

21. Leatham, G.F. (1985). Extracellular enzymes produced by the cultivated mushroom Lentinus edodes during degradation of a lignocellulosic medium. Appl. Environ. Microb.50, 859-867.

22. Leatham, G.F.; Leonard, T.J. (1989). Biology and physiology of shiitake mushroom cultivation. Shiitake mushrooms: A national symposium and trade show, the center for alternative plant and animal products. University of Minnesota, St Paul, p. 19-46.

23. Leatham, G.F.; Stahmann, M.A. (1989). The effects of common nutritionally-important cations on the growth and development of the cultivated mushroom Lentinula edodes. In: Grabbe, K.; Hilber, O. (eds). Mushroom Science XII. International Society for Mushroom Science. Braunschweig, p. 253-265.

24. Leifa, F.; Pandey, A.; Soccol, C.R. (2000). Solid state cultivation an efficient method to use toxic agro-industrial residues. J. Basic Microb.40, 187-197.

25. Leonowicz, A.; Matuszewska, A.; Luterek, J.; Ziegenhagen, D.; Wojtás-Wasilewska, M.W.; Cho, N.S.; Hofrichter, M.; Rogalski, J. (1999). Biodegradation of lignin by white rot fungi. Fung. Genet. Biol. 27, 175-185.

26. Luo, X. (2004). Progress of xiang-gu (shiitake) cultivation in China. In: Rinker, D.L.; Royse, D.J. (eds). Science and cultivation of edible and medicinal fungi. Penn State Univ., Press, Pennsylvania, p. 317-322. 
27. Martínez-Carrera, D.; López-Martínez de Alva, L. (2010). Historia del cultivo comercial de hongos comestibles en México II: éxitos y fracasos durante el período 1991-2009. In: Martínez-Carrera, D.; Curvetto, N; Sobal, M; Morales, P; Mora, V.M. (eds). Hacia un Desarrollo Sostenible del Sistema de Producción-Consumo de los Hongos Comestibles y Medicinales en Latinoamérica: Avances y Perspectivas en el Siglo XXI. Red Latinoamericana de Hongos Comestibles y Medicinales-COLPOSUNS-CONACYT-UAEM-UPAEP-IMINAP, Puebla, p. 513-551.

28. Mata, G.; Gaitán-Hernández, R. (1994). Avances en el cultivo del shiitake en pulpa de café. Rev. Iberoam. Mic.11, 90-91.

29. Mata, G.; Salmones, D.; Guzmán, G. (1990). Cultivo del shiitake japonés, Lentinus edodes, en bolsas con viruta de madera. Rev. Mex. Mic.6, 245-251.

30. Mata, G.; Savoie, J.M.; Delpech, P.; Olivier, J.M. (1998). Reduction in the incidence of Trichoderma spp. Using substrate supplementation with peat and an alternative spawn during cultivation of Lentinula edodes on pasteurized wheat straw. Agronomie 18: 515-520.

31. Morais, M.H.; Ramos, A.C.; Matos, N.; Oliveira, E.J.S. (2000) Production of shiitake mushroom (Lentinus edodes) on lignocellulosic residues. Food Sci.Technol. Int. 6, 123-128.

32. Morales, P.; Martínez-Carrera, D. (1991). Bursera sawdust as a substrate for shiitake cultivation. Micología Neotropical Aplicada 4, 41-47.

33. Morales, P.; Martínez-Carrera, D.; Martínez-Sánchez, W. (1991). Cultivo de shiitake sobre diversos substratos en México. Micología Neotropical Aplicada 4, 75-81.

34. Muñoz, C.; Guillén, F.; Martínez, A.T.; Martínez, M. J. (1997). Laccase isoenzymes of Pleurotus eryngii: characterization, catalytic properties and participation in activation of molecular oxygen and $\mathrm{Mn}^{2+}$ oxidation. Appl. Environ. Microb. 63, 2166-2174.

35. Oei, P. (2003). Mushroom cultivation: appropriate technology for mushroom growers, CTA, Wageningen.

36. Philippoussis, A.; Diamantopoulou, P.; Zervakis, G. (2002). Monitoring of mycelial growth and fructification of Lentinula edodes on several agricultural residues. In: Sánchez, J.E.; Huerta, G.; Montiel, E. (eds). Mushroom biology and mushroom products. UAEM, Cuernavaca, p. 279-287.

37. Philippoussis, A.; Diamantopoulou, P.; Zervakis, G. (2003). Correlation of the properties of several lignocellulosic substrates to the crop performance of shiitake mushroom Lentinula edodes. World Journal of Microbiology and Biotechnology 19, 551-557.

38. Pire, D.G.; Wright, J.E.; Alberto, E. (2001). Cultivation of shiitake using sawdust from widely available local woods in Argentina. Micologia Aplicada International 13, 87-91.

39. Przybylowicz, P.; Donoghue, J. (1990). Shiitake growers handbook. The art and science of mushroom cultivation. Kendall/Hunt Publishing Company, Dubuque.
40. Rajarathnam, S.; Wankhede, D.B.; Bano, Z. (1987). Degradation of rice straw by Pleurotus flabellatus. J. Chem. Technol. Biot. 37, 203-214.

41. Rajarathnam, S.; Shashirekha, M.N.; Bano, Z.; Ghosh, P.K. (1997). Renewable lignocellulosic wastes - the growth substrates, for mushroom production: national strategies. In: Rai, R.D.; Dhar, B.L.; Verma, R.N. (eds). Advances in mushroom biology and production, MSI, Solan, p. 291-304.

42. Road, R.; Naik, D.G. (1990). Influence of two levels of N \& S on the growth and lignolytic ability of Pleurotus ostreatus on wheat and paddy straw. Indian J. Anim. Nutr. 7, 71-74.

43. Royse, D.J. (1985). Effect of spawn run time and substrate nutrition on yield and size of shiitake mushroom. Mycologia 77, 756-762.

44. Royse, D.J.; Sánchez, J.E. (2001). Influence of substrate wood-chip particle size on shiitake (Lentinula edodes) yield. Bioresource Technol. 76, 229-233.

45. Salmones, D.; Mata, G.; Ramos, L.M.; Waliszeski, K.N. (1999). Cultivation of shiitake mushroom, Lentinula edodes, in several lignocellulosic materials originating from the subtropics. Agronomie, 19, 13-19.

46. Sánchez, J.E.; Royse, D.J. (2002) La biología y el cultivo de Pleurotus spp. Limusa-Grupo Noriega Editores, Tapachula.

47. Sánchez, A.; Ysunza, F.; Beltrán-García, M.J; Esqueda, M. (2002). Biodegradation of viticulture wastes by Pleurotus: A source of microbial and human food and its potential use in animal feeding. J. Agr. Food Chem. 50, 2537-2542.

48. SAS Institute, (1998). SAS/STAT User's guide, release 8.02 Version; SAS Institute Inc.: Cary.

49. Silva, E.M.; Machuca, A.; Milagres, A.M.F. (2005). Evaluating the growth and enzyme production from Lentinula edodes strains. Process Biochem. 40, 161-164.

50. Song, C.H.; Cho, K.Y.; Nair, N.G. (1990). Effect of triacylglycerols on growth, lipid profile and lipase activity of Lentinula edodes. Mush. J. for the Tropics 10, 9-19.

51. Song, C.H.; Cho, K.Y.; Nair, N.G.; Vine, J. (1989). Growth stimulation and lipid synthesis in Lentinus edodes. Mycologia 81, 514-522.

52. Stamets, P. (1993). Growing gourmet \& medicinal mushrooms, Ten Speed Press, Hong Kong.

53. Van, C.H.; Drage, T.C.; Snape, C.E. (2003). Biodegradation of oak (Quercus alba) wood during growth of shiitake mushroom (Lentinula edodes): a molecular approach. J. Agr. Food Chem. 51, 947-956.

54. Valeriano, V.S.; Silva, A.M.F.; Santiago, M.F.; Bara, M.T.F.; Garcia, T.A. (2009). Production of laccase by Pycnoporus sanguineus using 2,5 - xylidine and ethanol. Braz. J. Microbiol. 40: 790-794.

55. Velázquez-Cedeño, M.A.; Mata, G.; Savoie, J.M. (2002). Waste- 
reducing cultivation of Pleurotus ostreatus and Pleurotus pulmonarius on coffee pulp: changes in the production of some lignocellulolytic enzymes. World J. Microb. Biot. 18, 201-207.

56. Wasser, S.P.; Weis, A.L. (1999). Medicinal properties of substances occurring in higher basidiomycetes mushrooms: current perspectives (review). Int. J. Med. Mushrooms 1, 31-62.
57. Zelenak, I. (1990). Lignocellulose materials, Nonconventional Feedstuffs in the Nutrition of Farm Animals. In: Bodá, K.J. (ed), Developments in animal and veterinary sciences. Bratislava, Czechoslovakia, p. 63-87.

58. Zheng, Z.; Shetty, K. (2002). Solid-state bioconversion of phenolics from cranberry pomace and role of Lentinus edodes B-glucosidase. J. Sci. Food Agr. 48, 895-900. 